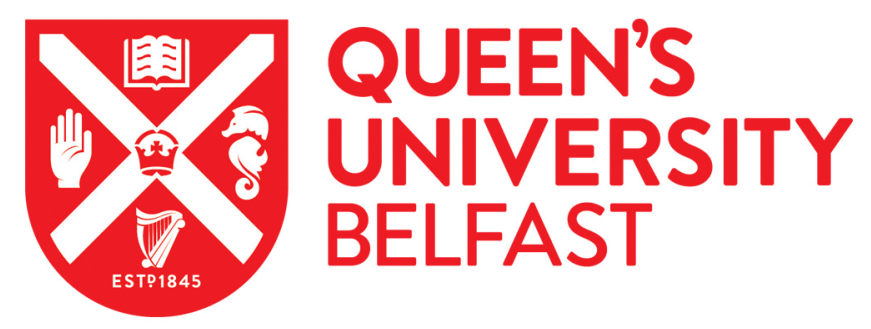

\title{
Public services and charities: Accounting, accountability and governance at a time of change
}

Hyndman, N., \& McKillop, D. (2018). Public services and charities: Accounting, accountability and governance at a time of change. The British Accounting Review, 50(2), 143-148. https://doi.org/10.1016/j.bar.2018.01.001

\section{Published in:}

The British Accounting Review

Document Version:

Peer reviewed version

Queen's University Belfast - Research Portal:

Link to publication record in Queen's University Belfast Research Portal

Publisher rights

Copyright 2018 Elsevier. This work is made available online in accordance with the publisher's policies. Please refer to any applicable terms of use of the publisher.

\section{General rights}

Copyright for the publications made accessible via the Queen's University Belfast Research Portal is retained by the author(s) and / or other copyright owners and it is a condition of accessing these publications that users recognise and abide by the legal requirements associated with these rights.

Take down policy

The Research Portal is Queen's institutional repository that provides access to Queen's research output. Every effort has been made to ensure that content in the Research Portal does not infringe any person's rights, or applicable UK laws. If you discover content in the Research Portal that you believe breaches copyright or violates any law, please contact openaccess@qub.ac.uk. 
Accepted Paper British Accounting Review (Accepted January 2018)

\title{
Public Services and Charities: Accounting, Accountability and Governance at a Time of Change
}

\author{
Noel Hyndman ${ }^{1}$, Donal McKillop
}

\begin{abstract}
A B S T R A C T
This special issue is based on a selection of papers initially presented at the conference on 'Public Services and Charities: Accounting, Accountability and Governance at a Time of Change' (Centre for Not-for-profit and Public-sector Research, Queen's University Belfast, January 2017). 'Public services and charities' is a distinctive grouping that includes organisations that are not-for-profit and often have wide social and cultural goals that drive mission and actions. These organisations operate in a very fluid environment. Expectations of the public at large and of government are changing; economic pressures bear down on them particularly acutely; performance metrics and a push for marketisation reflect a spirit of the age; 'business practices' are frequently afforded a reputation of being 'good' and applicable in all settings; while news reporting and social media often amplify any perceived shortcomings. The papers included in this special issue present an opportunity to reflect on some of the key changes taking place with respect to accounting, accountability and governance in this setting. Such opportunities to reflect can support evaluation of the stated objectives of implemented and proposed changes, and also help to inform policy making within government and elsewhere. Key arguments made in these papers, and the overarching themes of this special issue, are explored in this editorial.
\end{abstract}

Key words: Public services; Charities; New Public Management; Not-for-profit

${ }^{1}$ Corresponding author. Email address: n.hyndman@qub.ac.uk 


\section{Public services and charities: big and pervasive}

The term 'public services and charities' is a rather loose title given to one of the special interest groups in the British Accounting and Finance Association. It is, nevertheless, a title that captures something idiosyncratic about a grouping of certain vital organisations. What is distinctive about them, and what makes them different from businesses, is that they are not-forprofit, although that does not preclude them from making a surplus (or at least breaking even) in the running of their affairs (indeed, making sure that they have access to funds to cover their costs is normally essential to their survival). In addition, these organisations often have wide social and cultural goals that are absolutely central to what they do. 'Public services and charities' (for convenience, using the shorthand 'not-for-profit sector' elsewhere in this paper) is a broad term that covers public-sector organisations, as well as wider not-for-profit sector associations (such as charities, credit unions, microfinance institutions and social enterprise agencies). For illustration purpose, and to reflect the influence of these institutions, we focus on three subsets of this grouping (public-sector organisations, charities and credit unions), while acknowledging that many other types of organisation can fall within the not-for-profit sector.

\subsection{Public sector}

In general, the public sector consists of organisations that are owned and operated by the government (or its agencies) and exist to provide goods and services for its citizens. In addition, many governments engage in outsourcing by using businesses (and other organisations, such as charities) to deliver goods and services. This has been a particularly persistent feature in the UK over the last 25 years, especially with respect to the private finance initiative (PFI) and publicprivate partnership (PPP) arrangements whereby private sector organisations have built, financed and operated public-sector projects (for an annual fee) (Shaoul et al., 2011). The public sector is large, with the average percentage public-sector employment rate in Organisation for Economic Co-operation and Development (OECD) countries being approximately 19 per cent of the working population (OECD, 2015). In the UK, about 5.4 million people are employed in the public sector, 16.9 per cent of all people in work (Office for National Statistics (ONS), 2017).

\subsection{Charities}

Charities exist to provide public benefit (such as overseas aid, medical research, social welfare or education); benefit that may not be provided, or not provided to the same extent, without charitable recognition. They exist in most societies and are facilitated through various legal and administrative frameworks by, for example, major tax benefits and differing, and possibly lightertouch, legal and regulatory frameworks. The definition of a charity can vary according to the country in which the organisation operates. The charity sector in the UK is large. There are approximately 200,000 registered charities, and these have an estimated annual total income of $f^{8} 80$ billion. The sector includes a small number of very large charities, and a large number of very small charities. Among the largest charities are such well-known names as Cancer Research UK (annual income $£ 679$ million), Oxfam ( $£ 414$ million) and Barnardo's ( 2 $^{298}$ million). The sector employs over 800,000 people in the UK and is heavily dependent on volunteers; approximately 40 per cent of the UK population volunteers to work in charities at some stage each year (National Council for Voluntary Organisations (NCVO), 2017).

\subsection{Credit unions}

Credit unions are not-for-profit, cooperative, member-owned, voluntary, self-help, democratic institutions that provide financial services to their members. As member-owned, not- 
for-profit organisations they are value driven. Traditionally they have been seen as serving the financial services needs of disadvantaged communities and individuals. As the movement has developed, particularly in countries such as the USA, Canada, Australia and Ireland, credit unions have increasingly appealed to the professional classes and compete with other retail financial institutions for this client base. It is estimated that, worldwide, there are 68,000 credit unions, operating in 109 countries and serving 235 million members (World Council of Credit Unions (WOCCU), 2016) Microfinance institutions, many of which have adopted the credit union ownership form, provide access to finance to individuals normally excluded from mainstream financial services, particularly in developing countries. The mission of most microfinance institutions is to achieve financial sustainability and social goals simultaneously.

\section{Emerging challenges}

The not-for-profit sector has changed significantly over time. Indeed, expansion in the numbers and scope of charities, community-based financial co-operatives and social enterprise agencies has often been openly promoted by governments, sometimes based on policy objectives related to a perceived 'appropriate' balance of government and non-government activity. At the same time, major challenges have emerged. For example: faith in the charity sector has been questioned as a result of a number of high-profile scandals and this has prompted increasing calls for transparency (Hind, 2017); the efficacy of governance within the for-profit financial sector has been scrutinised as a consequence of the recent global financial crisis and resultant banking bailouts (Mehran et al., 2012); and resource constraints have been significant as a result of the financial crisis (and bailing out of for-profit financial institutions by government), most notably in terms of a perceived period of 'austerity' (Bracci et al., 2015).

Concurrent with this has been the growth in the New Public Management (NPM) ideology which has resulted in many governments throughout the world engaging in reform processes aimed at bringing business concepts, techniques and values into the public sector. This influence has also had a profound impact in the wider not-for-profit arena. This NPM movement has resulted in major shifts in management, accountability and governance systems; such shifts often being associated with a 'modernisation' agenda (Hyndman \& Lapsley, 2016). In such a scenario, words like accountability and performance management have proliferated in discussions and policy documents, despite the fact that these terms are rather difficult to define (and operationalise) in any commonly-agreed manner. In addition, what are often viewed as privatesector accounting instruments (in financial accounting, management accounting and performance measurement) are often embraced as providing support for NPM changes. For example, with respect to financial accounting in the not-for-profit sector (and particularly in the case of the public sector), the adoption of NPM ideas has frequently been accompanied by the replacement of cash-based systems (traditionally used in major parts of the sector) with more private-sector-type, accruals-based systems. Indeed, it is often argued that without such changes, any NPM modifications would be considerably weakened, with the belief often expressed that such alterations to accounting tools will facilitate better decision making and control (Likierman, 2003).

\subsection{New Public Management}

NPM is a collective term used to classify broadly similar public-sector reforms, the main themes having been identified (Hood, 1995, p. 95) as 'the idea of a shift in emphasis from policy making to management skills, from a stress on process to a stress on output, from orderly hierarchies to an intendedly more competitive basis for providing public services, from fixed to variable pay and from a uniform and inclusive public service to a variant structure with more emphasis on contract provision'. Such reforms have had a pervasive and enduring quality 
(Hyndman \& Liguori, 2016), despite the occasional claim that NPM has been replaced or has died (Osborne, 2010). With NPM, the 'need' for adjustments to established systems and approaches has often been promoted by policy makers and consultants/practitioners (Efficiency Unit, 1988), although many researchers have questioned the efficacy of such adjustments (Guthrie, 1998; Lapsley, 2009). The adoption of private-sector accounting tools (including accruals accounting) as support for the implementation of NPM ideas often portray this as a means of providing rational decision makers with appropriate information to make informed decisions. However, such changes are complex, and use 'expert talk' (Meyer \& Höllerer, 2010). Commonly, decision makers in the not-for-profit sector (including politicians in the public sector) often do not understand such tools and language. Moreover, such changes frequently lack a focus on not-for-profit issues (van Helden \& Reichard, 2016; Hyndman, 2016).

In the papers of this special issue, the impact of NPM (and the adoption of related accounting instruments) arises in a number of settings. For example, focusing on a period of fiscal austerity (where policies are sought to reduce government budget deficits), Heald and Steele (2018) consider the impact of the importation of private-sector governance arrangements into the UK public sector. They found that, despite ostensibly similar architecture to private-sector boards, members of public-sector boards were often excluded from any meaningful input to the development of strategy (a major aspect of a private-sector governance model). Moreover, such boards, via the assertion of political power, frequently experienced very blurred accountability requirements which made it difficult for them to operate effectively. Against this backdrop, a number of public bodies were abolished, merged or reconfigured, with surviving public bodies suffering deep budget cuts and reduced autonomy (evidence of a process of 'reterritorialisation'). In other research settings, it has been claimed that reforms have been introduced for reasons of 'external legitimation' (in order to portray an organisation as appropriate, rational and modern) rather than to improve its focus and operation (Meyer \& Rowan, 1977; DiMaggio \& Powell, 1983; Pina et al., 2009). Echoes of these ideas are found in Heald and Steele's (2018) research, with 'modern' governance processes being used to mask contentious cuts and closures, or at least to provide 'cover' for politicians regarding such decisions.

Also in this special issue, Liguori and Steccolini (2018), using debate transcripts from the Italian parliament, explored how language is used in a political setting to provide internal legitimation (or delegitimation) of NPM-related changes to accounting systems. In such a setting, it was found that the language used facilitated the exercise of power. The arguments deployed by politicians predominantly focused on legitimation (justifying) by use of authorisation (related to authority of tradition or law) and moralisation (related to legitimation by reference to specific value and ethical systems, such as accountability and transparency) strategies. The authors argue that the rhetorical arguments used by politicians allowed them to disguise their loss of power in favour of the European Union, and facilitated the depiction of their actions and proposals as necessary and/or in favour of the public interest (and thus provided a degree of external legitimation).

\subsection{Performance management}

Emerging as an important aspect of NPM, the measurement and management of performance has become a key focus for many organisations in the not-for-profit sector (Connolly \& Hyndman, 2003; van Dooren et al., 2015). The identification of indicators of output, outcome or impact (however these terms might be defined), and the pursuit of greater efficiency and effectiveness in the management and delivery of public and charitable services, have been highlighted as central in terms of both decision making and reporting in the not-forprofit sector. For example, this can be seen in the UK public sector in terms of the establishment of Executive Agencies following the Next Steps Initiative (NSI) (Efficiency Unit, 1988) and the importance placed on societal outcomes in the funding of activities in the delivery of social 
programmes (HM Treasury, 2011), as well as in a host of other changes in such areas as local government, health and education. A leitmotif in them all is that performance should be improved and such improvement must be measured in terms other than how much money is spent. In the charity sector similar themes are clearly evident. For example, the cross-sector group known as 'Inspiring Impact' seeks to encourage and support good practice in reporting on outcomes and impacts (Lumley et al., 2011) and has developed a Code of Good Impact Practice (Inspiring Impact, 2013). Moreover, it is argued that reporting by charities on impact can form the basis of improved effectiveness, accountability, legitimacy and trust (McConville, 2017). Indeed, the most recent Statement of Recommended Practice for charities (Charity Commission, 2014), an accounting and reporting template which is mandatory for all large charities in the UK, highlights the need for such focus. However, there are severe challenges faced by those developing performance management systems (PMSs) in the not-for profit arena. These include: setting objectives in complex organisations that have multiple stakeholders with competing needs; measuring the most important aspects of performance (which often occur in the long term and are affected by uncontrollable external factors); measuring quality (which is almost always more difficult to measure than quantity); ensuring the reliability of the information; and making meaningful comparisons (be it with targets, previous years or other organisations).

Evidence has been presented, and argument made, that inappropriate and over-reliance on PMSs and the metrics that they spawn can result in major dysfunctional (and often unanticipated) consequences, including tunnel vision, sub optimisation, mission drift, myopia, ossification and misrepresentation (Smith, 1995; van Thiel \& Leeuw, 2002; van Dooren et al., 2015). For example, the UK university sector, where the vast majority of universities are constituted as charities (although they receive substantial public-sector funding), has had formal, and long-standing, performance metrics imposed on it by government with respect to both teaching and research. This is most visible of late in terms of a Research Excellence Framework and a Teaching Excellence Framework (Martin, 2011; Higher Education Funding Council for England (HEFCE), 2017). The ideas contained in such frameworks stress 'business-like' logics of value for money, income generation and productivity; and these have become the norm in the sector. However, many have argued that the imposition and use of such PMSs is undermining, and in some cases replacing, the focus of universities on traditional educational values (including student development), and have resulted in substantial mission drift (Broadbent \& Guthrie, 2008; Parker \& Guthrie, 2012). It is suggested that such strict measurement and audit cultures which have developed has resulted in counter-productive outcomes, and the managerial oversight of academic work has reached a critical tipping point (Craig et al., 2014). Indeed, even early work by Prichard and Willmott (1997), reflecting on the pervasiveness of such PMSs within UK universities at a time when they were in their infancy, opined that there was a need to think carefully about measurement and accountability in ways that embrace more responsible features of a modified collegial control system.

Aspects of the difficulties and challenges of designing and operating PMSs are explored in the papers in this special issue. Investigating PMSs in large national arts organisations, Abdullah et al. (2018) found that systems that originated focusing on the collection, preservation and display of arts, adjusted significantly towards a financial focus in times of budget pressure. This both highlights the influence of socio-economic factors on the evolution of PMSs, and the power of salient external stakeholders to divert focus from what might be seen as key mission objectives within the organisation (and by the general public). Similar funding pressures were examined in much smaller organisations in Scotland (Henderson \& Lambert, 2018). Again the influence of funders was evidenced, along with the susceptibility to mission drift in the budget-constrained environment, as was the influence of key funders on the evolution of the PMSs. Nevertheless, in the cases that were examined, it was seen that, in a period of austerity, some charities were able to (at least to some extent) protect social mission despite high dependence on grant funding. This was achieved by meaningful engagement with funders and the flexibility (and agility) of 
management, which were viewed as mitigating factors that had the potential to reduce the potential negative aspects of such resource dependency.

\subsection{Accountability and trust}

A conventional view of accounting sees it as a purposive activity, directed towards a specified end, which is the meeting of users' (or stakeholders') information needs. While accountability is much more than accounting (no matter how widely one might define accounting), focusing on the information needs of users (or stakeholders) seems clearly linked with ideas relating to accountability, albeit that accountability is a fairly broad concept endowed with a variety of meanings (Connolly et al., 2017). At one level, accountability could be considered as being concerned with the giving of information by one party to another, to justify what has been done or what has been planned (Jackson, 1982). A wider perspective sees accountability as a relationship where parties are required to explain and take responsibility for their actions through the giving and demanding of accounts (Roberts \& Scapens, 1985). Similarly, Fry (1995) considers it in terms of 'public account-giving' that might include 'justifications, rationalisations, stories, excuses' (p. 184). In a not-for-profit organisation, this accountability relationship (between an account giver and an account receiver) is frequently summarised in terms of a principal-agent relationship, with the principal transferring resources to an agent with expectations that something will be done (Laughlin, 1990). These expectations then form the basis of the accountability relationship.

In considering accountability, two key questions often emerge: to whom is an organisation accountable, and for what is an organisation accountable? With respect to the 'to whom' question, there are many possible stakeholders that, in the language of stakeholder theory, are 'affected' or 'affect' the operation of not-for-profit organisations (Freeman, 1984). For example, there are both 'upward' stakeholders (such as government, regulators, funders and the public at large) and 'downward' stakeholders (such as beneficiaries or users of a service). Given the myriad of groups that might be considered stakeholders, the issue of how organisations can identify priorities in discharging accountability is critical. Mitchell et al. (1997), in exploring stakeholder saliency, argue that prioritisation will depend on the extent to which particular stakeholder groups possess three main attributes: power, legitimacy and urgency. Those that possess the greatest amount of these are described as 'definitive stakeholders', and, it is argued, their claims are likely to be prioritised. In terms of the 'for what' question, it has been argued that financial accountability (possibly via audited financial statements) has relevance (to indicate, for example: that money provided has been used for the appropriate purposes), but such accounts are likely only to be of secondary importance to many key stakeholders. This is because the objective of such organisations is not financially focussed, and money is not provided to generate financial returns. Other wider information, particularly relating to the key mission of the organisation in terms of what it does and what it achieves (performance), is likely to be paramount (Connolly et al., 2013). In this regard, Liñares-Zegarra and Wilson (2018) study the growth of microfinance institutions which follow the so-called 'double bottom-line' business approach: to achieve simultaneously financial performance and social objectives. Given the increasing importance of these institutions for key stakeholders (such as government, regulators, funders and financiallyexcluded borrowers), the authors explore the determinants of growth rates in 120 countries analysing a wide variety of ownership forms (micro-banks, NGOs, cooperatives/credit unions, and non-bank financial institutions) and the extent to which such organisations display a commercial orientation (profit versus not-for-profit). The authors find evidence that growth rates in the number of borrowers and in total assets for credit unions and microfinance institutions with a not-for-profit orientation present negative persistence (positive growth in one time period followed by negative growth in the next). Other factors affecting growth include levels of bad debt, efficiency and regulation. 
There are clear links between trust (a belief in the reliability, truth or ability of something or someone) and accountability. Common expectations regarding not-for-profit organisations are that they will both 'do good' (create positive change, do things that society values) and 'be good' (spend wisely, act ethically). While these expectations hold, stakeholders (funders, public etc.) continue to place trust in and support them; when these don't hold, trust is lost and damage results (Kearns, 2014). Scandals, however isolated, have the potential to inflict considerable damage that often goes far beyond the perpetrating culprit. These frequently arise when behaviour is at odds with the public's expectations. For example, in the UK charity sector in 2015, there was the much-publicised suicide of a 92 year-old poppy seller Olive Cooke (believed to have received almost 3,000 charity mailings in a single year), and there was the collapse of Kids Company amid allegations of financial mismanagement (Hind, 2017). A key contention is that good accountability supports the building of trust, and trust is essential to ensure the continuing health of organisations in the not-for-profit sector. Conversely, weak accountability damages trust, and damaged trust can inflict considerable cost on public services and charities more broadly. Good systems of accountability can provide a solid foundation for the building of trust (Bryce, 2016).

A number of these themes are explored in this special issue. Utilising in-depth interviews in two New Zealand charities (and employing recent developments in institutional theory), Yang and Northcott (2018) explored the challenges of measuring outcomes as a basis for discharging accountability. They found that charity actors engaged in institutional work aimed at discharging both identity accountability (whereby individuals within organisations feel a responsibility to be accountable to themselves with regard to the charity's values and mission) and upward accountability (to funders) via their outcome measurement practices. However, the charities faced difficulties in achieving a satisfactory balance between these two forms of accountability, creating the potential for mission drift. Also, on the basis of interviews in a range of large UK fundraising charities, Hyndman and McConville (2018) explored the interconnected and mutually reinforcing nature of both private (tailored to individual stakeholder group needs) and public (available to all) mechanisms in discharging accountability and building trust with key stakeholders. It was contended that significant trust was seen particularly as being developed through private accountability mechanisms that allowed 'voice' or 'participation'. In addition, it was asserted that trust requires transparency and informal contacts in order to allow for the building of critical relationships. On the basis of their analysis, they argue that the use and interplay of both private and public mechanisms has the potential to create a 'virtuous circle' of accountability and trust, whereby each reinforces the other.

\section{Concluding comments about this Special Issue}

A key objective of BAFA's Public Services and Charities SIG is to encourage accounting and finance research in not-for-profit organisations that is robust and relevant. These organisations are (or should be) very different from businesses: they have very distinctive missions that are not related to profit generation; they are firmly focused on delivering social and cultural goals; and they have traditional management (and governance) norms that are more concerned with partnering than controlling and directing. The sector has a wide and pervasive impact on society; the organisations within it (be they charities, public-sector bodies, credit unions or other associations) are frequently deeply admired and appreciated by the societies which they serve. The sector generates significant social capital. Levels of trust and confidence in the organisations that make up this not-for-profit sector are often high (albeit capable of significant damage by scandals, however rare these may be) and often reflect the great value and appreciation generated in the public at large.

However, public service and charitable organisations face a very fluid environment in which they operate. Expectations of the public and of government are changing; economic pressures 
bear down on them particularly acutely (especially because many of their services are provided on the basis of non-exchange transactions); metrics and a push for marketisation reflect a spirit of the age; 'business practices' are frequently (although perhaps inappropriately) afforded a reputation of being 'good' and applicable in all settings; and news reporting and social media operate in such a way as to amplify issues that have the potential to harm the sector as a whole. How not-for-profit organisations manage and respond to such pressures is critical. On the one hand, appropriate responses can help buttress the sector from criticism and enhance the legitimation of its role. On the other hand, inappropriate responses can undermine the missiondriven and ethically-sound focus that such organisations often have, and put at risk the value and trust that not-for-profit organisations enjoy. This special issue gives an opportunity to reflect on some of the key changes taking place with respect to accounting, accountability and governance in public service and charitable organisations. The contributions not only provide evidence to evaluate and guide the introduction of new practices and processes within the sector, but also seek to inform policy making within government and elsewhere. Overall, it is hoped that this input will support the shaping of better managed, more legitimate, more trusted and more accountable public service and charitable organisations.

\section{References}

Abdullah, A., Khadaroo, I., Napier, C. (2018). Managing the performance of arts organisations: Pursuing heterogeneous objectives in an era of austerity. British Accounting Review, xx (x), xxxx.

Bracci, E., Humphrey, C., Moll, J., Steccolini, I. (2015). Public sector accounting, accountability and austerity: More than balancing the books? Accounting, Auditing \& Accountability Journal, 28 (6), 878-908.

Broadbent, J., Guthrie, J. (2008). Public sector to public services: 20 years of "contextual accounting research". Accounting, Auditing \& Accountability Journal, 21(2), 129-169.

Bryce, H.J. (2016). The public's trust in nonprofit organizations: The role of relationship marketing and management. Nonprofit Quarterly, 11 January 2016.

Charity Commission (2014), Charities SORP (FRS 102) Accounting and Reporting by Charities: Statement of Recommended Practice. London: Charity Commission.

Connolly, C. and Hyndman, N. (2003), Performance reporting by UK Charities: Approaches, difficulties and current practice. Edinburgh: Institute of Chartered Accountants of Scotland.

Connolly, C., Hyndman, N. (2013). Charity accountability in the UK: Through the eyes of the donor. Qualitative Research in Accounting and Management, 10 (3/4), 259-278.

Connolly, C., Hyndman, N., Liguori, M. (2017). Charity accounting and reporting at a time of change. Dublin: Chartered Accountants Ireland.

Craig, R., Amernic, J, Tourish, D. (2014). Perverse audit culture and accountability of the modern public university. Financial Accountability \& Management, 30 (1), 1-24.

DiMaggio, P., Powell, W. (1983). The iron cage revisited: Institutional isomorphism and collective rationality in organisational fields. American Sociological Review, 2, 147-160. 
Dooren, W. van, Bouckaert, G., Halligan, J. (2015). Performance management in the public sector (second edition). London: Routledge.

Efficiency Unit (1988), Improving management in government: The next steps. Report to the Prime Minister. London: The Stationery Office.

Freeman, R.E. (1984). Strategic management: A stakeholder approach. Boston: Pitman.

Fry, R.E. (1995). Accountability in organisational life: Problem or opportunity for nonprofits? Nonprofit Management and Leadership, 6 (2), 181-195.

Guthrie, J. (1998). Application of accrual accounting in the Australian public sector - rhetoric or reality, Financial Accountability \& Management, 14 (1), 1-19.

Heald, D., Steele, D. (2018). The governance of public bodies in times of austerity. British Accounting Review, xx (x), xx-xx.

HM Treasury (2011). HM Treasury and Department for Work and Pensions: Green Book discussion paper on valuing social impacts. London: HM Treasury.

HEFCE (2017). About the TEF. Available on the internet at: http://www.hefce.ac.uk/lt/tef/whatistef/ Accessed 7 December 2017.

Helden, G.J. van, Reichard, C. (2016). Why cash-based budgeting still prevails in an era of accrual-based reporting in the public sector. Accounting Finance \& Governance Review, 23 $(1 / 2), 43-65$.

Henderson, E., Lambert, V. (2018). Negotiating for survival: Balancing mission and money. British Accounting Review, xx (x), xx-xx.

Hind, A. (2017). Fundraising in UK charities: Stepping back from the abyss. Public Money \& Management, 37 (3), 205-210.

Hood, C., 1995. The "new public management" in the 1980s: Variations on a theme, Accounting, Organizations and Society. 20 (2/3), 93-109.

Hyndman, N. (2016). Accrual accounting, politicians and the UK - with the benefit of hindsight. Public Money \& Management, 36 (7), 477-479.

Hyndman, N., Lapsley, I. (2016). New public management: The story continues. Financial Accountability \& Management, 32 (4), 385-408.

Hyndman, N., Liguori, M. (2016), 'Public sector reforms: Changing contours on an NPM landscape. Financial Accountability \& Management, 32 (1), 5-32.

Hyndman, N., McConville, D. (2018). Trust and accountability in UK charities: Exploring the virtuous circle. British Accounting Review, xx (x), xx-xx.

Inspiring Impact (2013). Our vision. Available on the internet at: http://inspiringimpact.org/about/our-vision/ Accessed 7 December 2017. 
Jackson, P. M. (1982). The political economy of bureaucracy. London: Philip Allan.

Kearns, K.P. (2014). Ethical challenges in nonprofit organizations: Maintaining public trust. In: Fredrickson, H.G., Ghere, R.K. (Eds.), Ethics in public management (pp. 265-292). New York: Routledge.

Lapsley, I. (2009). New Public Management: Cruellest invention of the human spirit? Abacus, 45 (1), 1-21.

Laughlin, R. (1990). A model of financial accountability and the Church of England. Financial Accountability \& Management, 6 (2), 93-114.

Liguori,M., Steccolini, I. (2018). The power of language in legitimating public-sector reforms: When politicians "talk" accounting. British Accounting Review, xx (x), xx-xx.

Likierman, A., 2003. Planning and controlling UK public expenditure on a resource basis. Public Money \& Management. 23 (1), 45-50.

Liñares-Zegarra, J., Wilson, J. (2018). The size and growth of microfinance institutions. British Accounting Review, xx (x), xx-xx.

Lumley, T., Rickey, B., Pike, M. (2011). Inspiring impact: Working together for a bigger impact. In: The UK social sector. Available on the internet at: http://inspiringimpact.org/wp-content/uploads/2012/06/inspiring_impact.pdf Accessed 7 December 2017.

Martin, B.R. (2011). The Research Excellence Framework and the 'impact agenda': Are we creating a Frankenstein monster? Research Evaluation, 20 (3), 247-254.

McConville, D. (2017). Transparent impact reporting in charity annual reports: Benefits, challenges and areas for development. Public Money \& Management, 37 (3), 211-215.

Mehran, H., Morrison, A., Shapiro, J. (2012). Corporate governance and banks: What have we learned from the financial crisis? In: Dewatripont, M., Freixas, X. (Eds.) The crisis aftermath: New regulatory paradigms (pp. 11-44). London: Centre for Economic Policy Research.

Meyer, R.E., Höllerer, M.A. (2010). Meaning structures in a contested issue field: A topographic map of shareholder value in Austria, Academy of Management Journal, 53 (6), 1241-1262.

Meyer, J.W., Rowan, B. (1977). Institutionalised organisations: Formal structure as myth and ceremony. American Journal of Sociology, 83, 340-363.

Mitchell, R.K., Agle, B.R., Wood, D. J. (1997). Toward a theory of stakeholder identification and salience: Defining the principle of who and what really counts. Academy of Management Review, 22 (4), 853-886.

NCVO (2017). UK Civil Society Almanac. London: NCVO.

ONS (2017). Statistical bulletin: Public sector employment, UK: June 2017. London: ONS. 
OECD (2015). Employment in the public sector: Government at a glance 2015. Paris: OECD Publishing.

Osborne, S.P. (2010). The (New) Public Governance: A suitable case for treatment?'. In: S.P. Osborne (Ed.), The New Public Governance? Emerging perspectives on the theory and practice of public governance. London: Routledge.

Parker, L., Guthrie, J. (2012). Accounting scholars and journals rating and benchmarking: Risking academic research quality. Accounting, Auditing \& Accountability Journal, 26 (1), 4-15.

Pina, V., Torres, L., Yetano, A. (2009). Accrual accounting in EU local governments: One method, several approaches, European Accounting Review, 18, 765-807.

Prichard, C., Willmott, H (1997). Just how managed is the McUniversity? Organization Studies, 18 (2), 287-316.

Roberts, J., Scapens, R. (1985). Accounting systems and systems of accountability understanding accounting practices in their organisational contexts. Accounting, Organizations and Society, 10 (4), 443-456.

Shaoul, J., Stafford, A., Stapleton, P. (2011). NHS capital investment and PFI: From central responsibility to local affordability. Financial Accountability \& Management, 27 (1), 1-17.

Smith, P. (1995). On the unintended consequences of publishing performance data in the public sector. International Journal of Public Administration, 18 (2/3), 277-310.

Thiel, S. van, Leeuw, F. (2002). The performance paradox in the public sector, Public Performance \& Management Review, 25 (3), 267-281.

WOCCU (2016), 2016 Statistical Report, Wisconsin: WOCCU.

Yang, C., Northcott, D. (2018). Unveiling the role of identity accountability in shaping charity outcome measurement practices. British Accounting Review, xx (x), xx-xx. 